\title{
Professionals' Attitudes towards Using e-Learning Implementation with Children with Disabilities
}

\author{
Ahmed Farouk Mohamed Saleh and Al-Farouk Ahmed Farouk Mohamed
}

\begin{abstract}
This study explored e-learning attitudes reported by (98) professionals working in the field of children with disabilities, $(60)$ teachers, (18) tutors working in diverse areas, (11) shadow teachers and (9) social workers, current study belongs to the pattern of descriptive analytical studies, a study Applied in ad hoc learning disabilities institution at Fayoum governorate south Egypt, The final results of Friedman technique confirmed that the attitudes of e-learning consists of three components Affective, Behavior and Cognitive components according (A,B,C) MODEL, cognitive Component has achieved the first rank in terms of the importance at (2.29), the next is Affective component at mean rank (2.02), the third and final rank is behavioral or skills component at (1.69). in the other hand result shows that E-learning implementation barriers consisted of five items, the test confirmed that the rank of items (1) to (5), Content-Suitability barriers is the first by mean rank (4.10), the last rank is the Instructional barriers by mean rank (1.66), results enable us to accept the null hypothesis: there is no significance difference in the professionals attitudes towards e-learning courseVary according to (educational level, position), in the other hand result showed accepts the alternative hypothesis: there is a statistically significant association at a level $(0.05)$ between e learning implementation barriers and staff attitudes towards e learning.
\end{abstract}

Index Terms - Children with disabilities, online learning, web learning, networked based learning, e-learning attitude, elearning course, affective component, behavioral component, cognitive component.

\section{INTRODUCTION}

This article provides an overview towards the role of elearning to promote the education of children with special needs, identify the level of professionals' attitudes towards e-learning courses, and identifies the e-learning implementation barrier Like all other educational sectors, " handicapped learning sector as well has not been able to remain isolated from the ongoing, one of the most critical challenge that most of the educational institution have been confronted with how to best educate children with disabilities for what has been variously called the Knowledge Age, the Information Age, or, more recently the Digital Age" [1].

As one of the important component of handicapped'

Manuscript received June 12, 2013; revised September 9, 2013.

Ahmed Farouk Mohamed Saleh is with Disabilities Department, Faculty of Social Work, Fayoum University, Cairo, Egypt (e-mail: afs01@fayoum.edu.eg).

Al-Farouk Ahmed Farouk Mohamed is with American school, Cairo, Egypt (e-mail: pharaohs-1999@live.com). learning, e-learning is a type of open or flexible learning for special needs, the new method of teaching and learning, and an imperative strategy in the educational reform creates new borderless learning environment and opportunities and bring dramatic changes in the character of students with disabilities. Ref. [2] E Learning with handicapped child depends on electronic communication online using the latest information and communication technologies. Ref. [3] This article tries to identify the levels of attitudes towards e learning by using the (A, B and C) model, this model enables us to measure the components of professionals' attitudes towards e learning courses with children with dishabilles.

\section{LITERATURE REVIEW}

The right to education is universal and extends to all children with disabilities. This right is enshrined in the Convention on the Rights of the Child (1989) [4] and the Convention on the Rights of Persons with Disabilities (2008). Ref. [5] It is also addressed in several international declarations, including the World Declaration for Education for All (1990), the UNESCO Salamanca Statement and Framework for Action (1994) [6], and the Dakar Framework for Action (2000) [7].

Due to several factors, including age, disease, accidents and other reasons, the number of people with disabilities increases every year. This increased number of people with disabilities is also reflected in educational fields, Millions of children across the developing counties cannot benefit fully from a traditional educational program because they have a disability that impairs their ability to participate in a typical classroom environment.

According to the results of several studies [8], [9] stated that the role of participation and interaction in learning activities was to valorize equally all students. In the other hand [10]-[13] found that Since learning is a social activity and understanding is socially constructed, e learning should be designed to promote participation, allowing all child to take part in all activities, enhancing cooperative learning and offering powerful opportunities [14].

During the last two decades, e-learning have been developing at an unprecedented and increasingly rapid pace specifically in the handicaps fields. The use of the Internet, the WWW and increasingly, virtual learning environments (VLEs) has revolutionized communications and is causing radical developments in the ways schools enable their staff and learners specifically child with disabilities to find and create knowledge and interact with each other [15]. 


\section{HYPOTHESIS DEVELOPMENT}

A number of studies attempt to identify the role of technology towards children with disabilities for example [16]-[21] found that depend on computer and access to internet enable us to improve the learning process for children with disability, in the other hand [22], [23] suggested that children with disabilities need to improve their attitudes towards e learning courses [24]-[26] found that the researchers need to design many studies enable us to identify the level and the components of e learning attitudes [27], [28] ([27]), helps us to identify the link between the personal and organizational variables and the attitudes towards e learning with disabilities, thus the main hypotheses of this study is: there is significant difference at the level of $(P$-Value $<0.05)$ in affective, cognitive and behavioral components according the organizational variables of professionals.

\section{Research Methodology}

The most significant limitation of this study is that it focused solely on educational organization in Fayoum governorate. In order to rectify this limitation, the study is being expanded to include all professions or the teamwork that enhance the educational process for children with disabilities. This measure is based on the three dimensions of professionals' attitude about e learning The questioner consist of (36) items, namely affective, behavior, and cognitive components, (A-B-C), and (6) items namely organizational variables, total items (66), Responses to these items were made on a 5-point Likert format ranged from $1=$ strongly disagree to $5=$ strongly agree.

The study was applied on (94) of professionals from disabilities fields in Fayoum governorate, the highest percentage $(61.2 \%)$ represented teachers, followed by the percentage $(18.4 \%)$, which represents tutors working in diverse areas, and (11.0\%), which represents shadow teachers, the percentage of at least $(13.3 \%)$ included social worker staff working in field of disabilities. The reliability of the questionnaire was tested according to Cronbach Alpha measurements; the reliability coefficient (Alpha) of each element of staff attitude was as follows: affective components (0.72); behavior components (0.80); and the cognitive components $(0.82)$, the reliability coefficients of all the three elements of total e learning attitudes were above (0.79). ) [29] (see Table II)

TABLE I: VALIDITY AND RELIABILITIES OF THE SCALE

\begin{tabular}{|c|c|c|c|c|c|c|}
\hline & Mean $^{\mathrm{a}}$ & $\begin{array}{c}\text { Std. } \\
\text { Deviation }\end{array}$ & A & B & C & E-L-A \\
\hline Affective component & 2.8243 & .6054 & $(0.721)$ & & & \\
\hline Behavioral component & 2.7830 & .7487 & ${ }^{*} .523$ & $(0.80)$ & & \\
\hline Cognitive component & 3.0121 & .7137 & *.635 & **.521 & $(0.82)$ & \\
\hline E learning attitudes & 2.8731 & .6435 & $\star * .634$ & $\star \star 654$ & $\star \star .760$ & $(0.79)$ \\
\hline
\end{tabular}

Results: Data in the table refers to the Rank of the components of professionals attitudes toward e learning with children with disabilities, using the Friedman test showed that the components of (1) to (3),Friedman test revealed a significant difference in responses at a lower level of (0.01), the test demonstrated validity and reliability of the three axes, the data in the table confirms that the cognitive component has the first order (2.29), followed by Emotional component in the order (2.02), in the order in the third and final skills component (1.69).

Is there a statistically significant difference in e learning attitudes according to position?Using Kruskal-Wallis to test the occurrence of significant differences between the all four sub-group (teachers, tutors, shadows and social workers). In three components (ABC) or professional attitudes, the results indicates that there was no significant differences between the four categories on the (ELA), because the significance probability above $(0.05)$ threshold. This Result enables us to reject alternative and accept null hypothesis that there is no significance difference between four subgroups as independent variable (see Table II).

TABLE II: THE RANKING OF E-LEARNING ATTITUDE COMPONENTS

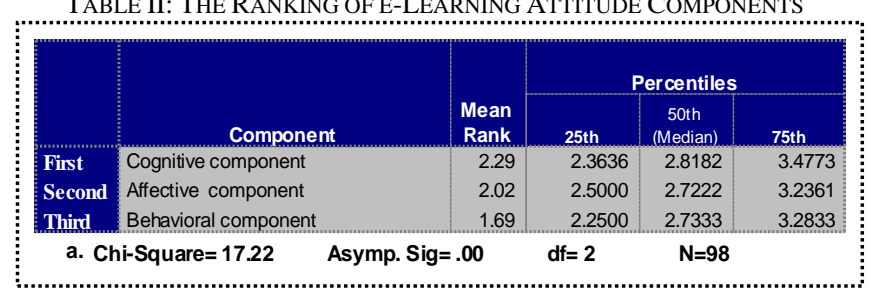

\section{SUMMARY}

This paper has focused on the staff attitudes towards e learning in disabilities fields, and presents an attempt to estimate the current e learning barriers, a Study applied on 98 professionals' responded to the questionnaire. The sample of the main research comprised of (98) of respondent. Out of which $(61.2 \%)$ teachers, $(18.4 \%)$ tutors working in diverse areas, $(13.3 \%)$ shadow teachers and $(11.0 \%)$ social workers staff working in the field of disabilities, current study belongs to pattern of descriptive analytical studies, a study Applied in ad hoc institution at Fayoum south Egypt. final results confirmed that the attitudes of e-learning consists of three components Affective, Behavior and Cognitive components according (A,B,C) MODEL, cognitive Component has achieved first rank at (2.29), the next is Affective component at (2.02), the third and final rank is behavioral or skills component at (1.69). E-learning implementation barriers consisted of five items, the test confirmed that the rank of items (1) to (5), the mean rank of barriers as follow Content-Suitability at first rank (4.1), Technological barriers at second mean rank (3.73), Organizational barriers at (3.04), Personal barriers at (2.47), and finally Instructional barriers at (1.66), results enable us to accept the null hypothesis: there is no significance difference in the professionals attitudes towards e-learning courseVary according to (educational level, position).

\section{REFERENCES}

[1] O. D. Ibironke, "Open-Minded Electronic Learning: Towards Enabling Cost-effective Lifelong Learning," in Proc. the 2006 Informing Science and IT Education Joint Conferenc, Informing Science and IT Education, USA, pp. 240-241, 2006.

[2] C. F Sacchanand, "Putting the Learners into E-learning: An Experience of Sukhothai Thammathirat Open University( STOU)," World Libaray And Information Congress: 74TH IFLA General Conference and Council Québec, Canada, 2008. 
[3] A. F. Nagy and Z. V. Karssen, "e-Learning E-Content Report 6 an integrating report by ACTeN Anticipating Content Technology Need," EU: E-Content Report delivered in the context of the EU-funded project ACTeN, 2004.

[4] CONVENTION ON THE RIGHTS OF THE CHILD. (1989). PART I: SUBSTANTIVE PROVISIONS. [Online]. Available: http://www.unesco.org/education/pdf/CHILD_E.PDF

[5] J. M. Guéhenno and K. W. Kang. (2008). Convention on the Rights of Persons. New York and Geneva. [Online]. Available: http://www.ohchr.org/Documents/Publications/AdvocacyTool_en.pdf.

[6] F. G. Mayor. (1994). The Salamanca Statement and Framework for action on special needs education. Spain. [Online]. Available: http://www.unesco.org/education/pdf/SALAMA_E.PDF.

[7] U. B. Barry and K. A. Brun. (2000). Dakar Framework for Action, Education for All: Meeting our Collective Commitments. Dakar. [Online]. http://unesdoc.unesco.org/images/0012/001211/121147e.pdf.

[8] S. Burgstahler. (2002). Distance learning: Universal design, universal access. Educational Technology Review. London. [Online]. Available: http://www.aace.org/pubs/etr/issue2/burgstahler.cfm.

[9] T. Waits and L. Lewis. (June 1, 2003). Distance education at degreegranting postsecondary institutions. U. S. Department of Education, National Center for Education Statistics. NCES. [Online]. Available: http:// www.nces.ed.gov/pubsearch/pubsinfo.asp?pubid=2003017

[10] T. Booth and M. Ainscow. (2007, March 11). Index for Inclusion: developing learning and participation in schools. CSIE. [Online]. Available: http://www.csie.org.uk/publications/inclusion-indexexplained.shtml

[11] Charter, European. (2004). E-leaning towards Social Inclusion, $\begin{array}{llll}\text { Barcelona. } & \text { EU. }\end{array}$ http://www.el4ei.net/first/charter\%20-\%20carta/charter_Elearnin.

[12] UNESCO. (2005). Guidelines for Inclusion: Ensuring Access to Education for All. Paris. [Online]. Available: http://unesdoc.unesco.org/images/0014/001402/140224e.pdf.

[13] M. A. Hoyle. (2008). Challenges affecting disabled in e-learning. EU. [Online]. Available: http://einiverse.eingang.org/tag/e-learning/.

[14] E. Guglielman. (2010). E-learning and disability: accessibility as a contribute to inclusion. [Online]. Available: www.mendeley.com/.../eleonora-gu.

[15] R. BLand. (2004). Educational Development: Discourse, Identity and Practice, Maidenhead: Society for Research into Higher Education and Open University Press. [Online]. Available: http://www.educatejournal.org/index.php/educate/article/download/2 $42 / 244$.

[16] C. S. Fichten et al., "Computer technologies for postsecondary students with disabilities I.," Journal of Postsecondary Education and Disability, vol. 11, 2001.

[17] C. Fichten et al., "Access to educational and instructional computer technologies for post-secondary students with disabilities: Lessons from three empirical studies," Journal of Educational Media, vol. 34, 1999.

[18] C. S. Fichten et al., "College students with disabilities. Dawson: Final report presented to FQRSC," Montréal: Adaptech Research Network, Dawson College, 2006.
[19] C. Fichten et al., Learning technologies: Students with disabilities in post-secondary education. Canada: Final report to the Office of Learning Technologies. Ottawa, ON: Human Resources Development Canada, 1999.

[20] L. A. Bissonnette, "Teaching and learning at Concordia University: Meeting the evolving education needs of faculty in providing access for university students with disabilities," Doctoral dissertation, Concordia University, Canada, vol. 231, 2006.

[21] A. M. Farouk, "Students with Disabilities' Attitudes towards Elearning courses in developing countries," International Conference in Bahrain. Kingdom of Bahrain: Zain center, Bahrain: Zain e learning cente, 2013, pp. 231.

[22] M. E. Fossey et al., "Development and validation of the Accessibility Of Campus Computing For Students With Disabilities Scale (ACCSDS)," Journal of Postsecondary Education and Disability, vol. $18,2005$.

[23] J. V. Asuncion et al., "Which forms of eLearning are accessible to Canadian postsecondary students with disabilities?" Journal of Postsecondary Education and Disability, vol. 187, 2007.

[24] T. Harding et al., "A comparison of the provision of educational supports to students with disabilities in AHEAD versus non-AHEAD affiliated institutions," Journal of Postsecondary Education and Disability, vol. 18, no. 2, pp. 234, 2006.

[25] A. M.Farouk, "Tutors' and students' Attitudes towards E-learning courses in Social Work," 22nd international Conference of $S W$ and improving the quality of life, Cario: Helwan university, pp. 64696470, 2009.

[26] A. M. Farouk, "Tutors' and students' attitudes towards Mobile learning in developing country," The Third Conference of e-learning and Distance learning Riyadh: National center for e learning and distance learning, 2013, pp. 331-332.

[27] O. Konur, "Computer assisted teaching and assessment of disabled students," Journal of Computer Assisted Learning, vol. 254, 2007.

[28] A. M. Farouk, "Instructors' and students' Attitudes towards Web based training courses in Social Work," Social Work and Human Seince Journal, pp. 5695-5696, October 1, 2011.

[29] J. C. Nunnally, Psychometric Theory, New York: McEvan-Hill, 1978.

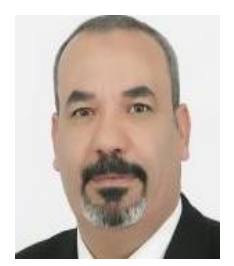

Ahmed farouk is a professor in fayoum university, faculty of social work, disabilities department. Prof Dr. Farouk's current research interests are in the areas of e learning with disabilities, online based training with children with disabilities, online social networking with disabilities and mobile learning with disabilities research.

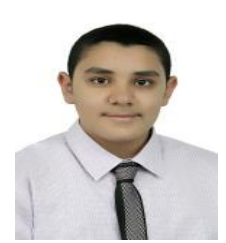

Al Farouk Ahmed was born in fayoum governorate. $\mathrm{He}$ is a student in the amerancan school, current research interests are in the areas of e learning implementation with students and e training with disabilities. 